\title{
THE INFLUENCE OF MULTI-FRONTAL TEACHING METHOD ON THE EFFECTIVENESS OF THE TEACHING PROCESS IN THE APPLIED STUDIES IN TECHNICAL SCIENCES
}

\begin{abstract}
The orientation towards equity and quality in education clearly imposes the need for individual approach to each student separately. This situation is especially pronounced in the higher education institutions of applied studies in the field of technology, whose primary goal is very often individual training for use of highly specialized software and hardware tools. In such a situation it is necessary to move away from classical ex-cathedra methodology, and to develop student-centred learning environments. The multi-frontal teaching method was until now experimentally analyzed at the level of primary and secondary education in Serbia, where it shows results that suggest additional research is warranted. The research presented in this paper aims to investigate the effectiveness of this method applied in higher education institution of applied studies in the domain of technology. Results of the conducted research indicate that the application of the multifrontal teaching method shows a positive effect on students' performance, self-efficacy and overall sense of personal gain and satisfaction.
\end{abstract}

Keywords: multi-frontal teaching method, effectiveness of the teaching method, selfefficacy, selfregulated learning, applied studies. 
Dragan Novković, Ilija Ćosić, Nebojša Petrović, Olja Jovanović

\title{
ИСПИТИВАЊЕ ЕФЕКТИВНОСТИ МОДЕЛА ВИШЕФРОНТАЛНЕ НАСТАВЕ НА СТРУКОВНИМ СТУДИЈАМА ИЗ ОБЛАСТИ ТЕХНОЛОГИЈЕ
}

\begin{abstract}
Оријентација образовног система ка праведности и квалитету Anстракm

образована је наметнула потребуза индивидуализованим приступом ученику/студенту. Ово је посебно наглашено у високообразовним институцијама струковних студија у области технологије, које често за примарни циљ имају индивидуални тренинг студената за употребу високоспецијализованих софтверских и хардверских оруђа. Имајући то у виду, ове студије захтевају померање од фронталне наставе на креирање окружења за учење/наставу које је усмерено на студента. Вишефронтални метод, којим се бавимо у овом раду, је до сада експериментално истраживан у основним и средњим школама у Србији, где је показао значајне резултате који су указали на потребу за даљим истраживањима. Истраживање које ће бити представљено је имало за ииљ испитивање ефективности модела вишефронталне наставе на струковним студијама из области технологије. Резултати указују да примена вишефронталног метода наставе показује позитиван ефекат на студентска постигнућа, самоефикасност и опити осећај личне добити и задовољства.
\end{abstract}

Кључне речи: вишефронтални метод наставе, ефективност наставног метода, самоефикасност, саморегулисано учене, струковне студије.

\section{ЭФФЕКТИВНОСТЬ МОДЕЛИ ФРОНТАЛЬНОГО ОБУЧЕНИЯ В ТЕХНИЧЕСКИХ ВУЗАХ}

\section{Резюме}

Ориентация образовательной системы на качество образования привелакпотребностив индивидуализированном подходе кучащимся. Это особенно подчеркивается в высшихучебныхзаведениях для профессионального обучения в области технологии, основной челью которых часто является индивидуальная тренировка студентов для применения узкоспециализированных софтверов. Обучение в этих заведениях требует перехода от фронтального обучения в направлении создания условий для интерактивного обучения, сосредоточенного на студента. Полифронтальный метод, который обсуждается в данной статье, был экспериментально исследован в основных и средних школах в Сербии, а полученные результаты указывают на необходимость дальнейших исследований. Данное исследование направлено на проверку эффективности полифронтальной модели обучения в технических вузах. Результаты показывают, что применение полифронтального метода обучения имеет положительное влияние на успеваемость студентов, самоэффективность и общее ощущение личного самоподтверждения. 
The influence of multi-frontal teaching method on the effectiveness of the teaching...

Ключевые слова: полифронтальный метод обучения, эффективность метода обучения, самоэффективность, саморегулируемое учение, профессиональное образование.

\section{Introduction}

From various perspectives, learning with information and communication technologies raises many hopes and expectations. Different solutions for learning with new media have been developed, e.g., web-based learning, videoconference systems, social software. Nowadays in many high education institutions, predominantly those offering study programs oriented towards technology and technical sciences, a substantial amount of educational activities has been conducted through, with and by means of computers and similar devices in an advanced technological teaching/ learning environment. This situation is even more pronounced at the faculties of applied studies. High-tech educational facilities in technological fields have very often a de facto case of enforcing individual instruction methods for a simple reason; namely, practical instruction on highly specialized software and/or hardware solutions and tools requires an individual approach and pace of learning in order to impart profound and applicable knowledge and aptitude to use any such tool or solution. This specific need for individual pace of learning that can be so often met on technical faculties clearly exposes all the fallacies of the classic, frontal ex cathedra educational system model, unfortunately still dominant in higher education institutions. Such situation presents a problem for students, but also for teachers who invest a lot of energy in the teaching process that is not properly adjusted to the existing situation.

In such situation, teaching approaches that can provide conditions for more individual approach to the student are required. These approaches usually facilitate student-centred, self-regulated learning. Various self-regulated learning theories share three basic assumptions (Zimmerman \& Schunk, 2001), namely that self-regulated learners are able to (a) personally improve their ability to learn through selective use of metacognitive and motivational strategies; (b) proactively select, organize, and even create advantageous learning environments; and (c) play a significant role in choosing the form and amount of instruction they need. In other words, students set their own learning goals, use many cognitive and metacognitive strategies to monitor, control, regulate, and adjust their learning to reach these goals (Pintrich 1995, 1999; Pintrich \& Zusho, 2002). Pintrich pointed out that self-regulatory activities mediate the relationship between personal and contextual characteristics and actual achievement or performance (Pintrich, 2004). For educators two strategies are generally used to nurture students' selfregulatory capabilities. One is to have teachers directly teach students skills needed for self-regulated learning in classroom. The other is an indirect approach of designing a learning environment in which students are offered authentic practices to actively experience the key processes of self-regulated learning (i.e. cognitive, metacognitive, and motivational), facilitated by educator or cognitive and metacognitive tools built in the computer-based learning systems (Azevedo, 2005). 
One of these indirect approaches is the multi-frontal teaching method (further MTM). The basic principles of this methodology, proposed by Serbian pedagogue Petar Savić (Savić, 1997), are:

(1) individual approach to each and every student;

(2) individual pace of learning that respects abilities and needs of each student;

(3) individualization of examination process;

(4) individualization of duration of the academic year;

(5) existence of two different types of learning/examining sessions throughout the whole academic year.

\section{Description of MTM Applied at the Higher-Education Level}

The multi-frontal teaching teaching method, as opposed to the commonly applied traditional frontal methodologies, allow the students to learn the syllabus at their own pace, or rather to accommodate their own individual abilities by adapting the learning rhythm to their own personal characteristics and capabilities.

Lecturing is taking place on "multiple fronts", because each student or group of students requires and employs a different lecture and learning pace, but still within the same classroom. The MTM approach by definition requires extensive and true individualisation of the teaching approach in which the teacher's role is that of a skilled learning 'facilitator' rather than of an 'expert'. Instead of being a passive consumer of the teaching process, each student becomes an active participant, but only at their own level, and in accordance with their own capabilities and their degree of current understanding. One of the main goals of MTM is that every student should open-mindedly develop knowledge and abilities on a personal and individual level, with parallel forming of a unique creative mind, thereby creating a fruitful environment for future self-education and the ability to continue to improve.

Other than the classical division that exists on faculties, theory lessons paired with auditory exercises, MTM lecturing functions in practice by employing two types of teaching sessions: Learning and Examination.

The first session type (learning), assumes that all students should have clearly defined places within the classroom or laboratory. Every student should have in their possession all required scriptures and books that handle the current syllabus topic, i.e. the one that the student is prepared to master during a particular lecture unit. At the beginning of the course, every student should be extensively informed about the study plan and the curriculum: the required number and content of lectures to be mastered and adopted should be made known, as well as the overall structure and the main goals of the course. In addition, when MTM is applied within specific group of students for the first time, it is necessary to spend some time at the beginning of the course on familiarising the students with the basic methods for successful learning.

All students attending the lecture are required to try to learn the lesson that they reached at this point, in an individual attempt, by learning the material at hand. 
The influence of multi-frontal teaching method on the effectiveness of the teaching...

The professor is present and ready to assist each and every student at any point where such assistance is needed (for instance, when during the learning process problems are encountered, questions need answering or something else is unclear). If the student requires help or needs to ask a specific question, the lecturer can temporarily switch into frontal lecturing mode, to clarify a term, a concept, a law or formula, or perhaps to address a larger problem with a task that seems too complicated for students.

All interactive forms of cooperation between students are strongly encouraged: sharing acquired knowledge, joined activities tackling well-defined problems, assistance provided by students that are more advanced, etc. Positive interaction generates stimulating working environments, where the ultimate goal of acquiring knowledge is being nurtured.

An MTM lecturer needs to transcend the traditional form of a mere lecturer. Instead of giving a speech, the lecturer gathers and accumulates the entire written and multimedia material, which is designed to help the student in an independent search of the necessary knowledge. Teaching staff can instigate lively discussions and a dynamic dialogue with students, who already have mastered a part of the said material and who have expressed their readiness to engage in such interactions. All questions that arise need to be answered and all help required needs to be available to students at any time during the lecture. The lecturer gradually establishes his or her authority by displaying impeccable professional knowledge and aptitude and through a close and fruitful working relationship with all students. Here, the role of the professor is to inspire, understand, encourage, motivate, direct and mentor all students based on his or her philosophical outlook in general, but also with their knowledge, experience, spirit, wit and expertise regarding the topic at hand.

The second type of teaching session (Examination) includes examination of the acquired knowledge. Students attending this class can volunteer to express their gained knowledge pertaining to the currently active topics (no actual limitation is given), which they have mastered and adopted. The role of the lecturer in this phase is of extreme importance. He or she estimates and assesses the actual knowledge the student has acquired and decides on one of two possible outcomes: the student has, in fact, adopted and understood the topic at hand and is eligible for a top grade, or the knowledge acquired is not complete and requires additional consideration and learning; thereby the lecturer should point out relevant scriptures and books, as well as other means that can help the student bridge the gap perceived by the lecturer. A grade is noted in the appropriately adapted grading document, which is specifically designed for this kind of setting.

In this teaching environment, students are also very important conveyors of knowledge, since their acquired knowledge can be now transferred to fellow students who did not reach that level yet. All students are required to present gained knowledge in front of the group, in a step-by-step mode, but each student can do it at his/her own pace. There are situations when some students do not actively participate during learning sessions, but during exam sessions they can observe and listen to other students presentations, using them as another source of learning. All students who attend examining sessions are nevertheless encouraged to ask questions and liven up the discussion even further. 
The lecturer actively monitors and participates in student presentations, corrects them when needed, supplements additional information and provides additional explanations, using such situation as another opportunity to encourage the learning process. Additional monitoring of actually gained knowledge and therewith the sustainability of such a learning process can be accomplished by including colloquia, tests and exams into the teaching process, if the teacher consider that there is a need for such a thing.

The student is deemed to pass the exam when he/she successfully presents the final lesson. This approach leads to the individualization of the school academic year: more successful students who have a faster pace of learning can finish the exam in a few weeks, while the less successful ones can take the whole academic school year to finish the same task. Advanced students who finish exams before the end of the semester are provided with additional activities, research work, practical problems etc., until the official end of the course, thus furthering their interest and effort in studying.

\section{Method}

The main goal of the research was to find out if there were differences in the effectiveness of the applied teaching methodology. The effectiveness of different teaching methods was defined by the students' satisfaction with different aspects of the teaching process, perceived self-efficacy and personal gains, and achieved grades on the courses Electroacoustics and Audio Engineering. Moreover, the research was aimed at exploring the influence of different variables (exam grade, self-efficacy for learning, personal gains) on students' satisfaction with teaching process in general.

Hypotheses. The hypothesis is based on the expectation that MTM is more effective than ex-cathedra teaching methodology due to the fact that MTM provides students with the possibility to learn at their own pace, to choose the time of the examination and to finish the course when it suits them, as well as to develop their independence. This effectiveness of teaching methodology is not measured only by final scores that students get, but also by the overall degree of course satisfaction, self-efficacy for learning and personal well-being that students have gained through the teaching process.

Sample. The sample included 74 first-year students of the Audio and Video Department at The School of Electrical Engineering and Computer Science Applied Studies in Belgrade, controlled by their entrance exam achievements, who were divided in two groups of equal size (37 students per group): control and experimental.

Procedure. At the beginning of the academic year first-year students were divided into two groups on two consecutive courses, Electroacoustics (first semester) and Audio Engineering (second semester). The groups was balanced - the students were selected alternately from the ranking list based on the entrance exam results. Namely, all students with an odd place on the list were put into a control group, while all students with an even place on ranking list become members of the experimental group.

In the experimental group, teaching was organized according to the MTM model, while the other group was subjected to traditional teaching methodology. At the end of the academic year, the questionnaires (to be discussed below) have been administrated to both groups. 
The influence of multi-frontal teaching method on the effectiveness of the teaching...

Variables. Dependent Variable: Effectiveness of teaching methodology quantitative variable that consists of four indicators: student's satisfaction with the courses; student's self-efficacy for learning; student's perception of personal gains; student's exam grades. Independent variable: Group - experimental and control.

Instruments. The questionnaire for evaluation of teaching methodology effectiveness is based on the questionnaire used for evaluation of the multi-frontal teaching method application at the secondary school level (Havelka, 2001), with the appropriate modification taking into account different levels of education.

Data Analysis. Data allow some basic statistics to be performed, mainly descriptive analysis. For evaluation of significant differences between two groups, the t-test was used. The regression analysis was used to predict students' course satisfaction from selfefficacy, perceived personal gains and exam grades.

\section{Results}

The results are presented in several thematic parts. In the first part, the data about the satisfaction of students with different aspects of teaching process within courses that were part of experiment will be presented. The second part deals with the way that students estimate their self-efficacy for learning. In the third part we will show how students observe the personal gains from the applied teaching methodologies. Fourth part deals with final grade comparison between these two groups. At the end, we will present in detail the relationship between the student exam grades and course satisfaction, self-efficacy and perceived personal gains.

\section{Students' satisfaction with different aspects of teaching process}

In general, all students report very high levels of satisfaction with the teaching process within Electroacoustics and Audio Engineering courses $(M=4.72, S D=0.562)$, without any significant differences between the control and the experimental group. A reason for this could be the above-average quality of learning conditions in which lectures within these two courses took place: a high-quality audio equipment and studio environment, many practical activities, etc. However, differences between these two groups can be observed when students are asked how satisfied they are with the acquired knowledge and experience $(\mathrm{t}=5.702, \mathrm{df}=72, p<.000)$, and learning assessment methods ( $\mathrm{t}=3.658, \mathrm{df}=72, p<.000)$. Namely, students from experimental group showed a higher level of satisfaction with both of those aspects of the teaching process $(M=4.78, S D=0.417 ; M=4.81, S D=0.397)$, in comparison to students from control group ( $M=4.24, S D=0.796 ; M=3.59, S D=1.235$ ).

\section{Students' self-efficacy for learning}

A relevant issue is that MTM is assumed to be correlated not only to the learner's capability to rightfully determine what, when and how to learn, but it also depends on 
their willingness to behaviourally or cognitively engage in learning. This suggest that the student-centred teaching methods involve more than technological or pedagogical considerations, so the learner's characteristics - such as their motivation and ability in monitoring and controlling one's learning in different settings - also need to be considered. Table 1 shows difference between self-evaluation of students from the control and the experimental group on self-efficacy for independent and autonomous learning, which is another essential principle of MTM. We examined self-efficacy with three questions, and in all three found statistically significant differences (respectively: $\mathrm{t}=-7.930, \mathrm{df}=72, p<.001 ; \mathrm{t}=-10.873, \mathrm{df}=72, p<.001 ; \mathrm{t}=-5.462, \mathrm{df}=72, p<.001)$.

Table 1. Students' evaluation of their self-efficacy for learning

\begin{tabular}{|c|c|c|c|c|c|c|c|}
\hline & \multicolumn{7}{|c|}{ Without detailed teacher lectures in the classroom, overcoming of subject matter is very difficult. } \\
\hline & $\begin{array}{l}\text { No, I don't agree } \\
\text { at all }\end{array}$ & I don't agree & I am undecided & I partly agree & $\begin{array}{l}\text { Yes, I agree } \\
\text { totaly }\end{array}$ & M & SD \\
\hline EG & 2.7 & 48.6 & 16.2 & 24.3 & 8.1 & 2.86 & 1.08 \\
\hline CG & - & - & 8.1 & 32.4 & 59.5 & 4.51 & 0.65 \\
\hline \multicolumn{8}{|c|}{ I do not feel capable for autonomously learning from textbooks and other materials, without teaching. } \\
\hline & $\begin{array}{l}\text { No, I don't agree } \\
\text { at all }\end{array}$ & I don't agree & I am undecided & I partly agree & $\begin{array}{l}\text { Yes, I agree } \\
\text { totaly }\end{array}$ & $M$ & SD \\
\hline EG & 45.9 & 48.6 & 2.7 & 2.7 & - & 1.62 & 0.68 \\
\hline CG & - & 18.9 & 5.4 & 40.5 & 35.1 & 3.92 & 1.09 \\
\hline \multicolumn{8}{|c|}{$\begin{array}{l}\text { For me it is too difficult task to independently learn and answer respectively } \\
\text { all lessons within those two courses. }\end{array}$} \\
\hline & $\begin{array}{l}\text { No, I don't agree } \\
\text { at all }\end{array}$ & I don't agree & I am undecided & I partly agree & $\begin{array}{l}\text { Yes, I agree } \\
\text { totaly }\end{array}$ & M & SD \\
\hline EG & 32.4 & 29.7 & 16.2 & 10.8 & 10.8 & 2.38 & 1.34 \\
\hline CG & - & 16.2 & 8.1 & 45.9 & 29.7 & 3.89 & 1.02 \\
\hline
\end{tabular}

Results suggest that students can achieve good results without the classical teacher lessons (CG results from Table 1), but it seems that after being subjected to MTM this opinion is significantly enhanced. The students from the experimental group agree in greater extent that they can be independently involved in teaching process without a need for large engagement of the teacher.

\section{Students' perception of personal gains from applied teaching methodology}

Another important aspect of the teaching process evaluation is students' perceptions of personal gains resulting from the applied teaching method. Namely, students entering higher education for the first time are faced with a number of the 
The influence of multi-frontal teaching method on the effectiveness of the teaching...

challenges. Research shows that it is important for a higher education institutions to foster in their first year students a sense of control or regulation over their own learning process and a willingness to participate actively in the learning experience (Yorke, 2005). The personal gains, among others, include critical thinking, communication skills, selfesteem and self-awareness, as well as a positive attitude toward education.

Generally speaking, there is a statistically significant difference between students from the two groups in perception of personal gains from the teaching process that they've been subjected to $(t=17.876, d f=72, p<.000)$. The students who were in the experimental group estimate a significantly higher level of personal gains $(M=96.51$, $S D=10.642)$, compared to the students from control group $(M=60.62, S D=5.992)$.

Based on the results, it can be said that the application of MTM enhances development of self-esteem, motivation for learning, creative and working skills, internal locus control and other characteristics of a self-regulative student.

\section{Exam grades comparison}

Since the final course grades reflect the achievement of the course goals, a comparison of students' grades on two courses has been made. For the purposes of this study the results of the joint tests that students from both group took at the end of each semester have been used.

Results show that there is no significant difference in final grades on the Electroacoustics course between the students from the control and the experimental group. On the other hand, exam grades on the Audio Engineering course between these two groups differ significantly $(\mathrm{t}=2.789, \mathrm{df}=72, p<.05)$. Namely, the students from the experimental group have earned significantly higher grades on course of the Audio Engineering $(M=7.73, S D=1.387)$ than students from the control group $(M=6.95, S D=0.998)$.

Such result may be caused by differences in subject content and time required for effects to be noticed. The course of Electroacoustics largely relies on the theoretical knowledge of physics that students bring with them from their previous schooling. Considering that both groups were statistically equal as far as their previous education and entrance exam, the lack of significant differences in the scores at this course should not be surprising. On the other hand, a course of Audio Engineering is based on engineering skills that students encountered for the first time in their education. In addition, this course includes a large part of practical training with audio equipment in which students were forced to adopt a good part of knowledge through their own independent work and autonomous learning, which is common during applied studies. With regard to time required for effects to be noticed, results show that differences in grades between experimental and control group become evident after a year of experimental teaching/learning. Namely, students from the experimental group were already used and trained for this kind of teaching/learning during the first semester on course Electoacoustic, so that could be an explanation for the better results that they have achieved after a year on the final exam of the course Audio Engineering. 


\section{Perception of teaching process as a predictor of satisfaction with it}

In order to evaluate if the cognitive and non-cognitive factors of learning can predict satisfaction with the teaching process, we applied the multiple regression analysis. As criteria we used the perception of the student's general satisfaction with those courses. The following variables are used as predictors: self-efficacy for learning, personal gains achieved through certain kind of teaching process and the final grades.

The regression model thus obtained has been statistically important ( $F(3$, $70)=3.783, p=.014)$. We have found a statistically significant corelation between the set of predictor variables and the criterium variable $(R=0.374)$, so this model explaines $14 \%$ of variance of the dependent variable.

The personal gains is the only significant predictor of general satisfaction of the teaching process, while the contribution of other predictors was not statistically significant, as can be seen in Table 2 .

Table 2. Partial regression coefficient for MTM with satisfaction with teaching process as criteria variable, with Self-efficacy, Personal gains and Final grade as predictors

\begin{tabular}{llllll}
\hline & \multicolumn{5}{c}{ Satisfaction with teaching process as a whole } \\
\cline { 2 - 6 } Variables & $B$ & $S E B$ & $\beta$ & t statistic & $p$ \\
\hline Personal gains & $\mathbf{0 . 0 1 2}$ & $\mathbf{0 . 0 0 5}$ & $\mathbf{0 . 4 2 2}$ & $\mathbf{2 . 5 6 7}$ & $\mathbf{. 0 1 2}$ \\
Final grade & -0.009 & 0.006 & -0.181 & -1.596 & .115 \\
Self-efficacy & 0.017 & 0.027 & 0.106 & 0.640 & .524 \\
\hline
\end{tabular}

\section{Conclusion}

Social changes, such as globalisation, international economic interdependences and focus on competencies have led to the awareness that both individuals and institutions need to engage in lifelong learning. Therefore, higher education has been critized for not developing competences, such as critical thinking, self management and ability to solve novel and complex problems, which are needed for professional expertise in modern society (James \& Pollard, 2011). This situation is especially pronounced in the higher education institutions of applied studies in the field of technology, whose primary goal is training for the use of highly specialized software and hardware tools. In such a situation it is necessary to move away from the classical ex-cathedra methodology, and to find-out teaching model that shows greater efficiency not only in terms of the final grades and the overall knowledge of students, but also in terms of forming the students as a subjects that will be qualified, motivated and self-sufficient in the continuous process of self-education. In addition to these core objectives of the educational process, the overall feeling of personal gain and satisfaction of the students, as well as their positive attitude towards the education, should also be taken into consideration as a measure of teaching process effectiveness. 
The influence of multi-frontal teaching method on the effectiveness of the teaching...

The MTM has until now been experimentally analyzed at the level of secondary education in Serbia (Havelka, 2001; Gajić i sar., 2006), where it shows results that recomend this method for additional research. The research presented in this paper was aimed at exploring the effectiveness of the MTM at the level of a higher education institution of applied studies in the domain of technology. Results of the conducted research indicate that the application of the MTM confirms the initial hypothesis that this method has a positive effect on teaching process effectiveness, as far as the students' performance, self-efficacy and an overall sense of personal gain and satisfaction of students who are subjected to this type of teaching.

Students who were subjected to MTM at the end of the school year showed a higher degree of satisfaction with the important aspects of teaching process, namely the obtained knowledge and experience, as well as the applied examination methodology.

The students' self-efficacy for independent and autonomous learning is another important aspect of the teaching process that showed statistically significant differences between these two groups that went in favor of the experimental. The students from the experimental group have greater confidence that they can be involved in the teaching process without a need for an extensive teacher input, which in each case presents a good foundation for sustainability of positive attitudes towards independent and autonomous learning in their further education.

Students from the experimental group showed a higher degree of satisfaction regarding their personal gain that was achieved through the teaching process. The results show that the application of MTM leads to the development of characteristics that distinguish a self-regulative student: students from the experimental group expressed a higher level of self-confidence, motivation for learning, creative and working skills as well as an internal locus of control.

Although different teaching methods that were applied in both groups use different methods of examination, for the purposes of objective comparison of the final grades all students were doing identical tests. Our results show that there is no significant difference in the final Electroacoustics grades between the students from either group, but at the same time the exam grades on Audio Engineering course between these two groups differ significantly. This result may indicate that the MTM shows better efficiency in terms of success on the final exam for those courses that involve a greater degree of practical training and does not rely in such extent on previously acquired knowledge, which is common in schools of applied studies in the field of technology.

Presented research was conducted in real-life conditions with a relatively small sample. Replication of these findings in another setting, would be desirable to confirm the initial results and establish that they generalize to other settings where the intervention might be implemented.

On the basis of presented results, it can be concluded that the application of this method leads to a certain shift in the overall effectiveness of the teaching process. Such finding suggests that the MTM deserves to be further investigated as a method that can elevate the efficiency of the teaching process, especially in courses which involve a good deal of practical training for students who are trained in the field of technology. 


\section{References}

Azevedo, R. (2005). Using Hypermedia as a Metacognitive Tool for Enhancing Student Learning? The Role of Self-Regulated Learning. Educational Psychologist, Vol. 40, No. 4, 199-209.

Gajić, O., Daljifi, Đ., Gužalić, D. i Narančić, J. (2006). Model višefrontalne nastave - efekti primene u nastavi psihologije. Nastava i vaspitanje, God. 55, Br. 1, 5-21.

Havelka, N. (2001). Odnos učenika prema eksperimentalnoj i tradicionalnoj nastavi u Srednjoj tehničkoj PTT školi u Beogradu. Nastava i vaspitanje, God. 50, Br. 5, 459-500.

James, M. \& Pollard, A. (2011). Principles for Effective Pedagogy: International Response to Evidence from the UK Teaching and Learning Research Programme. New York: Routledge.

Pintrich, P. R. (1995). Understanding Self-Regulated Learning. New Directions for Teaching and Learning, Vol. 63, No. 1, 3-12.

Pintrich, P. R. (1999). The Role of Motivation in Promoting and Sustaining Self-Regulated Learning. International Journal of Educational Research, Vol. 31, No. 6, 459-470.

Pintrich, P. R. (2004). A Conceptual Framework for Assessing Motivation and Self-Regulated Learning in College Students. Educational Psychology Review, Vol. 16, No. 4, 385-407.

Pintrich, P. R. \& Zusho, A. (2002). The Development of Academic Self-Regulation: The Role of Cognitive and Motivational Factors. In A. Wigfield \& J. S. Eccle (Eds.), Development of achievement motivation (pp. 249-284). San Diego: Academic Press.

Savić, P. (1997). Nova škola. Beograd: Školski PTT centar.

Yorke, M. (2005). Increasing the Chances for Student Success. In C. Rust (Ed.), Improving Student Learning 12: Diversity and Inclusiveness (pp. 35-52). Oxford: Oxford Centre for Staff and Learning Development.

Zimmerman B. J. \& Schunk D. H. (2001). Reflections on Theories of Self-Regulated Learning and Academic Achievement. In B. J. Zimmerman \& D. H. Schunk (Eds.), Self-Regulated Learning and Academic Achievement: Theoretical Perspectives (pp. 289-307). New Jersey: Lawrence Erlbaum Associates Publishers.

\section{Подаци о ауторима}

Драган Новковић је предавач на Високој школи електротехнике и рачунарства струковних студија у Београду.

E-mail: dragannovkovic72@gmail.com

Др Илија Ћосић је редовни професор на Факултету техничких наука Универзитета у Новом Саду. E-mail: ilijac@uns.ac.rs

Др Небојша Петровић је ванредни професор на Одељењу за психологију Филозофског факултету Универзитета у Београду.

E-mail: nebojsha.beograd@gmail.com

Оља Јовановић је истраживач-сарадник на Филозофском факултету Универзитета у Београду.

E-mail: oljajovanovic.ps@gmail.com 